\title{
Afghanistan After 2014
}

\section{Konarovsky}

Mikhail Konarovsky, PhD - Lead Researcher, Centre for East Asian and Shanghai Cooperation Organisation Studies, MGIMO; Ambassador Extraordinary and Plenipotentiary; Member, Russian International Affairs Council; 76 Prospect Vernadskogo, 119454 Moscow, Russian Federation; E-mail: makonarovsky@gmail.com

\begin{abstract}
Rather than improving, the situation in Afghanistan has further deteriorated after the withdrawal of the majority of American troops from Afghanistan. The ruling elite, despite having firm support from Washington and the West in general, has not been able to achieve the necessary degree of consolidation and the government formed after the presidential elections in 2014 remains politically shaky and vulnerable. The national economy depends heavily on foreign financial and economic injections. The 10-year economic program to promote selfsufficiency has not had a meaningful effect.

The government of Afghanistan failed to launch negotiations with armed opponents who endorsed the complete withdrawal of U.S. and North Atlantic Treaty Organization (NATO) forces. The Taliban continues to maintain control over a significant part of the country's territory. Along with intensive military operations, it conducted large-scale terrorist attacks in cities including Kabul. Simultaneously, the infiltration of fighters from the Islamic State of Iraq and the Levant (ISIS) to eastern and northern areas has increased significantly.

Neighboring countries, including Russia, continue to express concern over instability and increased ISIS activity and point to the perils of drugs and terrorism spreading from the territory of the Islamic Republic of Afghanistan. Viewing these issues as potential threats to regional security, Afghanistan's neighbors have made efforts to provide assistance to Kabul to support its efforts toward national reconciliation.

The accession of the new U.S. administration to power has not changed Washington's principal approach towards Afghanistan. Moreover, an increase in the presence of military and NATO forces in that country has been considered and could further heighten tensions in Afghanistan.
\end{abstract}

Key words: Afghanistan; National reconciliation; The Taliban; ISIS; U.S. policy, Russia

For citation: Konarovsky M. (2017) Afghanistan after 2014. International Organisations Research Journal, vol. 12, no 3, pp. 242-253 (in Russian and English). DOI: 10.17323/1996-7845-2017-03-242

Two major developments were unfolding in Afghanistan in 2014, making this a notable period in the country's recent history. The first was related to an external factor, namely the decision of Barak Obama's administration to withdraw the majority of American troops from the country. The process was carried out amid ongoing efforts to suppress armed opposition and a growing backlash by the country's population and government

${ }^{1}$ The editorial board received the article in March 2017. 
against the presence of foreign troops, and U.S. forces in particular. ${ }^{2}$ The second factor was internal, related to the fact that the country's presidential election was held against a backdrop of sharp internal instability and the relentless activity of the armed opposition. The situation was further aggravated by the country's dependence on foreign aid and drug production which to some degree became the pillars of the economy of Afghanistan.

The long-lasting and painful process leading up to the presidential election stretched from the spring to the fall of 2014, and highlighted the divisions among ruling elites who were unable to take firm steps towards unity even shortly before the reduction of the foreign military presence in Afghanistan. The personal ambitions of the key claimants to leadership in a country fraught with interethnic and interregional contradictions led to a stalemate when it came to identifying the winner of the election. To break the deadlock, Washington asserted influence both overtly and behind the scenes resulting in a Washington-sponsored deal that declared Ashraf Ghani to be the new leader of the country and his longtime political opponent Abdullah to be the "chief executive" of the national unity government. The fact that the latter post is not defined in the constitution of the Islamic Republic of Afghanistan made this position, and the new ruling coalition itself, both politically and legally vague. The long and complicated process to form Afghanistan's government underscores lasting internal political uncertainties.

To overcome the emerging dilemma, Ghani and Abdullah struck a deal on the separation of powers which included the immediate formation of a new electoral commission and a new supreme constitutional body - the Loya Jirga - to amend the constitution and organize new parliamentary elections. However, real efforts in this area were made only after further pressure was applied by the West just prior to the donors' international conference in Brussels in October 2016. Even still, the election issue remains unsettled. ${ }^{3}$

The key domestic and foreign policy objectives of the national unity government were presented in Ghani's inauguration speech. Ghani underlined security problems, negotiations with Talibs, the fight against terrorism and the production of drugs as pressing issues. In addition, Ghani presented a new policy intended to "reset" the Afghan economy based on significant foreign financial and economic assistance in support of a gradual transition to self-sufficiency. The most important part of the speech was the commitment to comprehensive governmental reform, including reform of the public authorities' triad, increased efficiency of defensive and security bodies, greater attention to human rights and other issues.

${ }^{2}$ This was reflected in the defiant refusal of President Karzai to sign an agreement on security with the United States. After the troops' withdrawal, an agreement was required to determine the scope of further assistance, including financial aid, to the Afghan security forces which were almost totally funded by Washington. Without this, an agreement on a new downsized training format for NATO troops in the country could not be signed. In the meantime, all key security functions in the country were officially shifted to the Afghan authorities, and foreign troops' participation in the war against the armed opposition was understood to be exceptional in nature.

${ }^{3}$ At that, the term limit of the parliament's lower chamber expired in summer 2015. 


\section{Domestic Policy}

Kabul made several unsuccessful attempts to initiate negotiations with the Taliban with the participation of the U.S., China, Pakistan, Qatar and other parties; the immediate withdrawal of foreign troops from the country remained the key requirement of the armed opposition but it viewed partial withdrawal as an opportunity to tilt the balance of power in the country. Consequently, after 2014 the key characteristic of Afghanistan's internal development was the steady increase of the Taliban's influence in various regions in Afghanistan, including its northern parts. The opposition mounted several military operations on a greater scale, and less seasonably determined, than before. Large terrorist attacks were carried out in cities, including Kabul. According to various estimates, by late-2016 up to one-third of the country's territory was beyond the government's control. U.S. air strikes only aggravated the population's sensitivity to the foreign military presence. At the same time units of the Afghanistan security forces (the army - 190,000 men; the police - 160,000 men) were inefficient and incapable of fundamentally addressing the situation.

The lack of real unity remained a key challenge for the leadership of the national unity government as well as for the armed opposition. Many Taliban field commanders continued to struggle for maximum discretion in military and political affairs. The death of Taliban founder and leader Mullah Omar in late-2015 and the confirmation of Mullah Mansour as his successor did not bring significant changes. During a lengthy truce the Taliban split into three groups, thus creating opportunities for the national unity government in its fight against its adversaries, allowing it to find common ground with some while sowing discord among others. However, at the same time this fact hampered Kabul's attempts to find a real dialogue partner among the armed opposition.

In the fall of 2016 a peace agreement was reached with the Hezbi Islami leader Gulbuddin Hekmatyar, one of the most odious and conceited adversaries of the regime, but it has not yet tipped the balance of power between the government and the armed opposition. The authorities committed to give Hekmatyar full amnesty, secure the lifting of sanctions imposed by the UN (the decision has already been made), guarantee the personal security of Hekmatyar and other Hezbi Islami activists as well as their participation in the country's political life and to set some of its detained followers free. In return, Hezbi Islami expressed readiness to cease military activity against the government and to recognize the country's constitution, among other things. The agreements were considered successes by the Ghani government; however it remains unclear whether they will serve as examples for other groups hostile to Kabul and it may even be that the agreements could pose significant potential risks for the national unity government. Hekmatyar, well known for his lack of principles and political disingenuity, will definitely strive to use his current position to strengthen his influence over all of Kabul's power structures. Preserving extensive relations with the Taliban, Al-Qaeda 
and the Islamic State of Iraq and the Levant (ISIS) gives Hezbi Islami's leader additional opportunities for political and military maneuvers. ${ }^{4}$

Remaining tensions and power struggles in the governmental coalition will help the Hezbi Islami leader to achieve his goals. Despite Ghani's public assurances that the national unity government is stable and fully reconcilled with Abdullah, conflict emerged in November 2016 between Ghani and first Vice-President Abdul Dostum, who represents the interests of the Uzbek minority in northern Afghanistan. Earlier that year the president had failed to oust Atta Muhammad - a powerful Tajik activist and governor of one of the most important northern provinces.

The recent emergence of ISIS fighters introduces a new actor in the conflict and has changed the general situation in Afghanistan, sparking new uncertainties regarding national reconciliation. Statistics on ISIS in Afghanistan are ambiguous. ${ }^{5}$ At first, relations between the Taliban and ISIS forces largely comprised of fighters from China's Xinjiang Uyghur Autonomous Region were hostile. However, relations have begun to improve due to certain changes in ISIS tactics. The phenomenon of the so-called Islamic State in Afghanistan internationalizes the terrorism issue in the country. Although these relations create more problems for Kabul authorities, the situation also justifies government demands for extra financial and military aid from the international community in the foreseeable future.

It is very likely that Kabul, following this pattern, will insist on becoming a full member of the Shanghai Cooperation Organization (SCO) as soon as possible. Kabul may also try to capitalize on the growing concerns of Russia, China and the Central Asian republics about the possibly destructive impact of ISIS on stability in the regions north of Afghanistan. The existence of these concerns was illustrated by the SCO summit declaration signed in Astana, 8-9 June 2017, that expressed the shared understanding of the SCO parties (including new members, namely India and Pakis$\tan )$ concerning the need to resume the SCO - Afghanistan Contact Group working process. $^{6}$

\footnotetext{
${ }^{4}$ Recently the Hezbi Islami leader has claimed that he would join ISIS and that he was an adherent of the "Khorasan Caliphate."

${ }^{5}$ Data presented in a special report by the U.S. Special Inspector General for Afghanistan Reconstruction John Sopko in November 2016 suggests that the total number of armed insurgents in the country was 45,000. The report notes that in August 2016 only $63 \%$ of the country's districts were under control of the national unity government while the insurgents occupied up to $30 \%$. According to the data, in 2016 the Afghan National Army's losses increased significantly. In 2015 personnel losses included 15,000 wounded and 5,000 killed. In the first eight months of 2016, the Afghan National Army has suffered losses of 10,000 wounded and over 5,500 killed. At the same time, U.S. sources claim that in the first quarter of 2017 the number of ISIS insurgents located in the eastern part of the country has declined. According to estimates presented by U.S. military officials, significant numbers of new ISIS forces, predominantly from Central Asia, arrived in Afghanistan in the fall of 2016 .

6 "The Astana Declaration of the Heads of the State of the Shanghai Cooperation Organization." Available at: http://eng.sectsco.org/documents/
} 


\section{The Economy}

Afghanistan is still unable to solve complex economic problems without large-scale foreign aid. An international conference was held in London in late-2014 to examine the country's economic problems and prompt the international community to provide further financial and economic aid. The national unity government confirmed its commitments to take measures to lower state spending and increase state revenue (by broadening the tax base in particular), and also to make structural changes, strengthen financial discipline, improve the investment climate for private business (including foreign business), strengthen public authority and administrative capacity as well as to undertake additional socially oriented efforts. The conference supported the government's efforts in the social and economic spheres and described them as forming "a relevant framework" for achieving the country's goals. At the same time, the donor nations linked their future contributions to the country's economic and financial sectors to the achievement of meaningful progress in comprehensive economic and social reforms by the government.

The London document has become a roadmap for Afghanistan aimed at fulfilling ambitious plans for the coming decade. In this context, western experts tend to emphasize the social and economic achievements of Afghanistan in their assessments of outcomes in the last two years. These achievements include increased life expectancy and decreased infant mortality, education and health successes, developing civil infrastructure, the gradual establishment of civil society and other accomplishments. However, these successes do not alter the basic fact that an excessive budget deficit (\$1 billion in 2015) remains the most pressing of Afghanistan's financial and economic dilemmas. The task of increasing the efficiency of customs duties remains unfinished, as does the identification of new sources of state revenues (although the government has made certain progress in this direction).

In October 2016 the regular international representative conference, attended by more than 100 countries and international organizations including the United Nations (UN), was held in Brussels under the auspices of the European Union (EU) and the ministry of finance of Afghanistan. The conference continued the London process. Its leading motive was to support actions of the national unity government, encourage it to undertake further reforms and provide further assistance until 2024. Remarks by U.S. Secretary of State John Kerry set the general tone for the conference. On behalf of the United States, he pledged full support for the peace process in the country and confirmed the commitment to "deepen our strategic partnership" with Afghanistan and provide further assistance to the country [Kerry, 2016]. Ahmad Hakimi, Afghanistan's minister of finance, highlighted improvements in some economic indicators, the realization of several economic projects, judicial system reform, increasing tax revenues, the fight against corruption, achievements in the social sphere and human rights protection.

The conference pledged to provide Afghanistan with $\$ 15.2$ billion by 2020 . The final communique stated that the country faces significant challenges which require fur- 
ther finance and resource mobilization. The conference expressed its support for "the political process without preliminary conditions" and vigorously urged ongoing work on elections reform, the holding of parliamentary elections in 2017 and the continued fight against corruption [Brussels Conference on Afghanistan, 2016].

\section{Foreign Policy}

In its foreign policy, Afghanistan's government did not proclaim reliance on the U.S. although the survival of the regime seems unlikely without support from the U.S. and western countries in general in the foreseeable future. Indeed, the agreement on cooperation in the security sphere signed between Kabul and Washington immediately after overcoming the power stalemate in Afghanistan and the agreement with the North Atlantic Treaty Organization (NATO) on the status of the Resolute Support Mission troops which replaced the International Security Assistance Force (ISAF) suggest that this is a high priority for Afghan authorities. These agreements confirm the importance of military cooperation with the West for Kabul and offer a kind of insurance in case there is further internal deterioration.

The 2016 NATO summit declaration in Warsaw stated the intention to extend the Alliance's mission beyond that year due to ongoing armed opposition in northern, eastern and north-eastern regions of Afghanistan. It also committed to providing financial assistance to the Afghan National Army (ANA) until 2020 with an extension until 2024, after which Kabul would be expected to take full responsibility for funding ANA and security forces. Providing support for reconciliation in the country and a peace process headed by the Afghans themselves "based on respect for the Constitution" was presented as the top priority [Ibid.], even while in some sense this contradicts the Brussels conference communique of October 2016. Following the conference, NATO leaders confirmed the importance of retaining a military presence in Afghanistan.

Kabul paid special attention to traditional Islamic considerations in its attempts to intensify its multidirectional foreign policy. This applied especially to relations with Saudi Arabia and Qatar, both of which played an important role in establishing dialogue with the Taliban. Recently these key Persian Gulf states have been struggling with each other for the right to maintain contacts with Kabul on their own territories. ${ }^{7}$ Compared to their neighbors, China and India have been central to the foreign strategy of the national unity government. During Ghani's time in office, China became the key vector in Afghanistan's foreign policy not only at the regional level, but also globally. China was the first country visited by the new president of Afghanistan (excluding his brief trip to the "holy places" in Saudi Arabia). Meetings there were aimed at the further development of bilateral economic ties and were also intended to confirm support for Kabul's attempts to revive its gridlocked dialogue with Pakistan to establish negotiations with the armed opposition. Special emphasis was put on the comprehensive

${ }^{7}$ While Qatar enjoyed the upper hand in the past as the Talibs set up their offices there and hosted delegations from Kabul, more recently Riyadh has stood out in terms of activity there. 
development of the previously declared "strategic partnership" with Beijing with a view to neutralizing Western presence in the country.

The government of Afghanistan takes into account the growing interest of China towards Afghanistan in economic matters - Afghanistan was included in China's "One Belt One Road" project. China is also interested in the security situation in Afghanistan due to China's appreciation of the increasingly destructive Afghan influence on the situation in China's western Muslim regions. Kabul's foreign policy priorities thus embrace a kind of coordination between China and the U.S. given China's interest in establishing broad "pragmatic cooperation" with Washington in Afghanistan [Li Qinguan, 2015].

As a part of the policy aimed at gradually transforming Afghanistan into a transport hub connecting Iran, Central Asia, India, China and the Indian Ocean, Afghan authorities have expressed growing interest not only in projects aimed at Afghanistan within the Istanbul process, but also in different aspects of the "One Belt One Road" initiative. ${ }^{8}$ Taking advantage of Beijing's growing attention to Afghanistan in its regional policy, Kabul actively backed Islamabad's proposal to turn the trilateral Afghanistan U.S. - Pakistan consultations into four-party negotiations. Although no success has yet been achieved, this fact is worth noting. Moreover, Beijing has previously mediated contacts between Kabul and the Taliban. However, as contacts between special forces and both parties have increased, China is becoming a more vigorous partner in Kabul's defense. In late-2014 China, Afghanistan and Tajikistan signed a trilateral agreement on joint border patrol in the Wakhan Corridor in Badakhshan province. However, conflict escalation and military clashes with Taliban forces impeded implementation of the agreement. Nevertheless, in 2016 bilateral antiterrorism drills took place in Tajikistan with China's participation.

Shortly after Ghani came to power, the president took a bold political step to intensify the peace process with the Taliban. He attempted to establish closer contacts with Pakistan and to set up defense cooperation and contact between special forces of the two countries. Despite the backlash in Afghanistan, both from the parliament and from key coalition partners, the parties managed to draft some pressing measures which would have had meaningful results. Bilateral trade and transit facilitation took shape. However, continuing activities behind the scenes by Pakistan's Inter-Services Intelligence (ISI) and its ongoing contact with the Taliban have virtually nullified these attempts, and Kabul's vigilance against Islamabad's activities in "Afghanistan's field" has renewed. ${ }^{9}$

While implementing the "strategic partnership" with India and countering Pakistan, Ghani's government carried out deliberate policy aimed at the further expansion of political and economic relations with Delhi. This is a longstanding focus for Afgha-

${ }^{8}$ In October 2016 China and Afghanistan reached another agreement regarding exploration of natural resources in Afghanistan. In September 2016 Afghanistan and China launched the first railroad project. Security issues, including the joint fight against terrorism and illegal drugs, are an important aspect of their bilateral cooperation. Their mutual determination is reflected not only in sharply increasing military contacts between both countries but also in the establishment of a four-party consultation mechanism on security issues along with neighboring Pakistan and Tajikistan.

${ }^{9}$ However, with assistance from Islamabad (and Beijing), Kabul managed to establish contacts with the Talibs; however, this made little difference to Kabul's efforts. 
nistan given the complicated relationships that Pakistan has with Kabul and Delhi - the shared anti-Pakistan sentiment that shapes relations between Afghanistan and India has never changed significantly and is not likely to in the future. With India providing assistance (earlier it gave Kabul a \$1 billion credit), the creation of several free economic zones and development of transit capacity in some small provincial Afghan airports are envisaged. Further, the completion of a large dam is planned for the spring of $2017 .{ }^{10}$

The closest northern neighbors of Afghanistan, the Central Asian nations, are alarmed about developments in Afghanistan but they continue to develop economic and political relations with Kabul in different formats. They justifiably apprehend the potential for a destructive influence on their internal stability if internal conflicts in Afghanistan escalate. ISIS activities in the northern provinces create extra nervousness in the region. The policy of these countries toward Afghanistan will most probably be shaped in the context of these factors.

Ghani did not mention Russia in any context in his keynote speech in the fall of 2014, suggesting that the relationship with Russia was not a high priority for the incumbent leaders of Afghanistan. The almost two-year absence from Russia of an Afghan ambassador after former President Karzai's uncle was recalled indicates the same..$^{11}$ However, Kabul has a pragmatic interest in gaining access to Soviet and Russian military equipment (mainly aircraft) and spare parts, and also in the reconstruction of some basic industries built by the Soviet Union in the 1950s-1980s. Similarly, Kabul could benefit from Russia's clout in Central Asia and its established relations with China, India, Iran and recently, Pakistan. Together, these factors prompted Kabul to be more flexible in its relations with Moscow. Meanwhile, given the implicit priority of the U.S. in Kabul's foreign policy, Afghanistan continued to follow the general policy of the U.S. toward Russia. This was confirmed by the viral anti-Russian campaign launched in Afghanistan and in the West after the Russian presidential envoy to Afghanistan explicitly mentioned Russia's partial contacts with the Taliban and after the trilateral meeting between Russia - China - Pakistan held in Moscow in late 2016 excluded Afghanistan. This, along with allegations by the commanders of NATO troops in Afghanistan in early-2017, and later about the alleged provision of Russian military supplies to the Taliban, was aimed at concealing the national unity government's difficulties and failures in tackling challenges of neutralizing the military capacity of its internal adversaries.

Moscow's long-term stance on Afghanistan stems from concerns about the remaining turmoil in Afghanistan and the lack of progress toward peaceful resolution of the conflict. The growing influence of ISIS in the country, especially in the northern

${ }^{10}$ Recently, vigorous efforts have been made within the context of trilateral agreements between Kabul, Iran and India to build the Chabahar port in the Persian Gulf. Afghanistan is set to have its own sea terminal there which would reduce Afghanistan's transit dependence on Pakistan significantly - permanently tense relations with Pakistan have a negative effect on virtually the entire Afghan economy. Setting up Afghanistan's consulate in Hyderabad in 2016 reflected the developing relations between Afghanistan and India.

${ }^{11}$ However, later the new Afghanistan president perceived his error and sought repeatedly to address the situation through his proxy, National Security Council secretary H. Atmar, as well as during the brief meetings with Russia's authorities, including on the sidelines of the Shanghai Cooperation Organisation summits. 
region, causes particular concern. Kabul's disposition for peaceful negotiations was confirmed by President Ghani at the international conference in Munich in February 2017, while Russia's support for this policy was confirmed during the trip of Afghanistan's minister of foreign affairs S. Rabbani to Moscow the same month. Russia is ready to establish constructive cooperation with Afghanistan to maintain its stability and independence as well as to promote negotiations while continuing assistance to its security forces. Besides terrorism, Russia is extremely anxious about the drug issue. Large-scale production of drugs funds and encourages terrorism and undermines regional stability. This focus area could become a more important sphere of cooperation between Moscow and Kabul.

At the six-party talks, held immediately after Rabbani's visit to Moscow, regional approaches to solving the Afghan problem were discussed. The parties reached agreements on stepping up efforts to facilitate the reconciliation process with Kabul in the lead role. They highlighted the need to broaden regional efforts aimed at stabilizing the situation and the need to engage new parties, mainly from Central Asia. Against this backdrop, Moscow has brought the Shanghai Cooperation Organization to the forefront - all members of this organization are neighbors of Afghanistan. The ascension of India and Pakistan to the SCO in June 2017 will significantly strengthen its position as the central regional forum in which a comprehensive solution to Afghanistan's problems can be sought. Recognizing that any hope of resolving Afghanistan's stalemate without the participation of Washington is unrealistic, Russia expresses interest in Washington joining the process. In this context, the renewal of U.S. - Russia dialogue on Afghanistan in the context of the NATO - Russia Council could be a positive sign.

\section{Conclusions}

Before the withdrawal of U.S. troops from Afghanistan and shortly thereafter, the expert community considered several scenarios regarding the further development of the situation in Afghanistan. One of the most optimistic and preferable scenarios envisioned the current regime remaining in power and being able to secure stability and the steady development of the country. Other less-optimistic scenarios see the opportunity to secure only partial control by the central authorities over regions, the de facto geographic and political defragmentation of the country, a slide towards chaos and "war of all against all" and ultimately the Taliban's total control over the country.

Despite remaining pressure by the armed opposition and lack of internal unity of the Afghan authorities, the worst-case scenario has been avoided over the last two years. Military operations have been carried out, the economy has floated and some announced reforms have been implemented. However, it is clear that this would not have happened without the presence of NATO troops (which take part in all Afghan National Army high-profile operations against insurgents), full fledged financial and other support for Afghanistan's security forces by Western countries and other members of the world community and their direct financial injections into the country's 
economy. Meanwhile, it is doubtful that by 2024 the national unity government will succeed in tackling all key challenges while carrying out its 10 -year program of social and economic reform. Completion of the reforms will definitely require time beyond this period.

A long period of internal confrontation lies ahead, even if some formal agreements on peace or truces are reached. Moreover, the national unity government's remaining course for reconciliation with the armed opposition, backed by the world community, provides some basis for thinking that Afghanistan tilts, although slowly and with backsteps, toward the hybrid option of tackling the challenge by sharing power with proactive Islamic opposition and establishing a kind of coalition with it (although probably with a limited timespan). However, it is necessary to significantly weaken the opposition to arrive at the negotiating table, and that remains quite problematic. The opposition's letter to U.S. President-elect Donald Trump in November 2016 made clear the Taliban's continuing demand for the withdrawal of U.S. troops. ${ }^{12}$ This approach was backed by Hekmatyar and, to a great degree, by former President Karzai. Before the U.S. presidential election in 2016 the lower house of Afghanistan's parliament had called again for revision of the security cooperation agreement with Washington which, among other things, had not only failed to ensure stability in the country but had aggravated it. For his part, President Ghani highlighted Washington's role as an "important strategic partner of Afghanistan in its fight against terrorism" and expressed hope for further development of bilateral relations. ${ }^{13}$

Needless to say, while the bulk of the armed opposition is reluctant to embrace the policy of national reconciliation announced by Kabul, the national unity government's viability depends totally on military and financial support from the U.S. and NATO. The severe aggravation of the situation in northern Afghanistan in 2015 made Washington delay the withdrawal of U.S. troops in 2016. That could have happened in 2017 but the final decision was left for the new U.S. administration led by Donald Trump. Although during his election campaign he was very skeptical about Washington's involvement in the IRA conflict, he nevertheless confirmed the commitment to the strategic partnership with Afghanistan and made clear the possibility of a troop surge in Afghanistan. The commanders of NATO troops in Afghanistan have openly backed the Alliance's troop surge. Kabul keeps a close watch on the details of current Washington policy and seeks by all means (including speculation about the "Russia factor") to encourage the U.S. to reinforce its Afghanistan policy in the style of former U.S. President Barack Obama.

Kabul, in this context, was impatient to learn how the White House's policy towards Afghanistan would evolve under President Trump. The new Afghan strategy, brought into action after long contemplation and calculation, dispelled the illusions concerning capabilities of Washington to consider substantial corrections to its policy towards Afghanistan. President Trump tried to distance his administration from claims made by

\footnotetext{
${ }^{12}$ According to khaama.com, 12 November 2016.

${ }^{13}$ According to president.gov.af/en (Press Release), 9 November 2016.
} 
the previous administration concerning firm and timely support for Kabul. He indicated that the U.S. will not intervene in matters of statecraft in Afghanistan, but emphasized the intention to concentrate on providing support for the Afghan security forces in their struggle against the armed opponents of the regime. In this case, withdrawal of the U.S. forces is not only the matter of doubtful future - the U.S. military presence is to be further increased. The strict reaction of the Taliban to these announcements is a preface to a new phase of conflict in Afghanistan. This is amplified by the fact that President Trump advocated for more active participation by India in Afghan issues when amending President Obama's "AfPak" conception. At the same time, President Trump sharply criticized Pakistan, blaming the country for its direct support of regional terrorist activity. All these factors led to active protest in Islamabad and China.

In keeping with Russia's skeptical appraisal of the "old-new" Afghanistan strategy adopted by the Trump administration, it is very unlikely that the Afghan conflict will move towards reconciliation in the near future. That would require new approaches from Washington. However, a radical "reload" of the U.S. strategy towards interior and international aspects of the Afghanistan crisis can be realized only if accompanied by general changes in its perception of its global strategic interests, which is unlikely.

The open and transparent cooperation of external actors as well as their forbearance from the temptation to seek unilateral advantages at the expense of their partners' interests (including the Afghan partners) should be a key element in promoting the Afghan peace process. Taking into account the history of the conflict in Afghanistan, it is quite clear that different factions in the incumbent national unity government as well as outside the government (including the Taliban) will seek to secure special support outside and inside the country with a view to impose their own decisions on other actors. It will be difficult to overcome this trend, especially given the deep mutual distrust not only between the U.S. and Russia but also between the U.S. and China, the U.S. and Iran, India and Pakistan, Afghanistan and Pakistan, and so on. These factors predetermine opportunities by laying the groundwork for biased and prejudiced interpretations of the other side's intentions, allowing actors to secure their own interests at the expense of the common strategic goal to promote peacemaking and the establishment of a negotiation process for national reconciliation. For these reasons, many new and unexpected challenges lie ahead.

\section{References}

Brussels Conference on Afghanistan (2016) Communique, 4-5 October. Available at: http://mfa.gov.af/ Content/Media/Documents/joint_communique26102016112741613553325325.pdf (accessed 15 August 2017).

Kerry J. (2016) Secretary of State. Remarks at the Brussels Conference on Afghanistan, 5 October. Available at: http://www.state.gov/secretary/remarks/2016/10/26786.htp (accessed 15 August 2017).

Li Qinguan (2015) Afghanistan Offers New Space for Sino-US Cooperation. China International Studies, November/December, p. 144. 


\section{Афганистан после 2014 года ${ }^{1}$}

\section{М.А. Конаровский}

Конаровский Михаил Алексеевич - к.и.н., ведущий научный сотрудник Центра изучения Восточной Азии и ШОС Института международных исследований МГИМО (У) МИД России, Чрезвычайный и Полномочный посол, член Российского совета по международным делам; Российская Федерация, 119454 Москва, просп. Вернадского, д. 76; E-mail: makonarovsky@mail.ru

После вывода из Афганистана основной части воинского контингента США обстановка в стране не только не претерпела радикальных позитивных изменений, но и имела тенденцию к обострению. Правящая элита, несмотря на поддержку Вашингтона и Запада, не смогла обеспечить необходимого единства, а сформированное после президентских выборов 2014 г. правительство оставалось шатким и политически уязвимым. Экономика функционировала в основном благодаря внешним финансово-экономическим вливаниям. Запущенная десятилетняя программа становления на путь самообеспечения не дала каких-либо ощутимых результатов.

Правительству не удалось запустить и переговорный процесс с вооруженными оппонентами, выступавшими за окончательный вывод войск США и НАТО. В руках талибов по-прежнему остается значительная часть территории страны. Наряду с интенсивными боевыми операциями проводились крупные террористические акты в городах, включая Кабул. Параллельно набирало силу и присутствие в Афганистане боевиков ИГИЛ.

Соседние государства, включая Россию, выражают серьезное беспокойство в связи с нестабильностью в Афганистане, расширением деятельности ИГИЛ, опасностью распространения с территории ИРА наркотиков и терроризма. Расценивая сложившуюся ситуацию как потенциальную угрозу безопасности региона, они оказывали содействие Кабулу и его курсу на национальное примирение. Москва изучает возможность расширения региональной составляющей решения афганской проблемы.

Приход к власти в США новой Администрации не внес каких-либо новых корректив в политику Вашингтона в Афганистане. Более того, рассматривалась, в том числе параллельно с НАТО, возможность расширения военного присутствия в этой стране, что в итоге может обострить афганский конфликт.

Ключевые слова: Афганистан; национальное примирение; талибы; ИГИЛ; политика США; Россия

Для цитирования: Конаровский М.А. Афганистан после 2014 года // Вестник международных организаций. 2017. T. 12. № 3. C. 242-253. DOI: 10.17323/1996-7845-2017-03-242

\section{Литература}

Brussels Conference on Afghanistan (2016) Communique, 4-5 October. Режим доступа: http://mfa.gov.af/ Content/Media/Documents/joint_communique26102016112741613553325325.pdf (дата обращения: 15.08. 2017).

Kerry J. (2016) Secretary of State. Remarks at the Brussels Conference on Afghanistan, 5 October. Режим доступа: http://www.state.gov/secretary/remarks/2016/10/26786.htp (дата обращения: 15.08.2017).

Li Qinguan (2015) Afghanistan Offers New Space for Sino-US Cooperation // China International Studies, November/December, p. 144.

\footnotetext{
${ }^{1}$ Первая версия статьи поступила в редакцию в марте 2017 г.
} 